\title{
Ideological Fluency and World Literature: The Cold War and the Case of Ismail Kadare
}

\begin{abstract}
This essay examines the role that geopolitical currents play in the translation and circulation of texts in the international literary market. Some of the central questions it asks are: what gets translated, published, and distributed, and why? What texts can enter the world literature canon? What role do international literary prizes like the Nobel Prize in Literature play in consecrating texts as belonging to world literature? The essay investigates patterns in the award of the Nobel Prize during the Cold War, and the justifications for the awards given. The analysis reveals the ultimately formative and homogenizing tendency of the prize, and of world literature-as-archive more broadly speaking. Using the case of Ismail Kadare, some of his contested works, and his questionable status as a dissident author, the article shows that writers from areas of geopolitical interest tend to become "fluent" in the logic of the literary market, producing texts that address and satisfy pressing socio-political concerns for, mainly, Western audiences.
\end{abstract}

Keywords: Albanian literature, Eastern European literature, international literary prizes, Ismail Kadare, literary markets, literary theory, world literature

The aim of this article is to analyse the role that political resistance has in the circulation of literary texts. Dissident, exile, and resistance writing from Eastern Europe during the Cold War and shortly thereafter is born transnational by virtue of a broad political and historical interest in the area from Western literary critics, diaspora groups in important Western cities, and Western publishers. Writers from Eastern Europe who produced texts that were overtly or covertly critical of Communist regimes were often motivated by the desire to influence change in their countries from within and without, but they were also ideologically fluent in how texts circulated on the international literary market. Sensing a demand for stories of Communist oppression in literary markets in Western nations, resistance writers produced works that dramatized and fictionalized the conditions on the ground, and were therefore included within a literary market that we identify as world literature. The primary examples for the discussion in what follows will be the works of the Albanian writer Ismail Kadare, especially because of the questions surrounding his status as a dissident, but it is important to emphasize that the same patterns of literary market fluency can be observed with other Eastern European writers.

2 Open Access. () 2021 Eralda L. Lameborshi, published by De Gruyter. (c) BY-NC-ND This work is licensed under the Creative Commons Attribution-NonCommercial-NoDerivatives 4.0 International License. 
In his study What is World Literature?, David Damrosch argues that world literature is a mode of production, circulation, and reading. A work can achieve world literature status, according to Damrosch, if its national context does not prevent it from gaining ground in a global context. Thus, one of the first conditions for works to be included under the rubric of world literature is that they must circulate beyond their country of origin "either in translation or in their original language” (Damrosch 2003, 4). Damrosch advocates what he calls "a phenomenology" rather than an ontology of the work of art, because the work of art "manifests differently abroad than it does at home" (2003, 6; emphasis in original). Conceptualizing literary texts as phenomena that rely on contextualization for meaning production demands a closer investigation of the forces at play: who is invested in the text outside of its national context and why? What interests drive the translation? In what ways does the translation cater to the audience's expectations? How does the writer of the literary text choose to accommodate or reject editorial demands placed on him/her from literary market pressures? Why is a particular text well received? How is it read abroad? How is it read at home? These and many other questions are made possible if we look at world literature texts as artistic sites that allow the critic to move beyond the existence of the text in one specific location. For Eastern European writers these questions are crucial, especially since the answers inform writers about the types of stories that can travel to Western audiences. Western publishing markets comprise the largest literary market in the world, and authors whose works are circulated within it benefit from the network of translators, agents, critics, editors, publishers, and so on whose role is crucial in establishing a world literary tradition.

It is here that I must clarify what I mean by ideological fluency and literary market fluency. Both concepts take their cue from the world literary market and its global demand for stories. Such fluency relies, also, on the ability of the local writer to produce works that are translatable to foreign markets. The authors themselves must have an understanding of how texts circulate, what ideas travel, and what stories are in demand. The concept of literary market fluency seeks to describe precisely the author's process of knowing, and this knowledge is possible because of the author's keen observation of the market's demands. While reading world literary production in such a manner may seem cynical and reductive, I argue instead that it is essential to our understanding of the ways in which world culture affects literary texts and vice versa. Texts read the world as the world reads the texts, and in this symbiotic relationship we witness the flourishing of world literature. In addition, examining the role that ideological fluency plays in literary production introduces a corrective gesture to literary studies that have traditionally relied on the analysis and monumentalization of canonical texts. Analysing ideological fluency allows writers and critics to engage with texts in a more trans- 
parent way, and it begins a process of dissolution of the spectre of the canon, which in itself places unquestioned and strict demands on writers of literature. The result is one where the writer has creative freedom to produce narratives that are neither influenced by a desire for canonical status nor rendered barren as a result of their enclosure within a world literature tradition.

I take my cue, largely, from Jacques Derrida's work Archive Fever. Derrida argues that archives are knowledge repositories where knowledge is arranged just so, according to a particular logic of place - historical, social, political, economic - and according to a specific logic of one's ability to retrieve knowledge. In other words, rather than making deposited knowledge accessible, archives are opaque, accessible only through the authority of the archivist, the curator, and the editor. Derrida writes:

The meaning of “archive," its only meaning, comes to it from the Greek arkheion: initially a
house, a domicile, an address, the residence of the superior magistrates, the archons, those
who commanded. The citizens who thus held and signified political power where consid-
ered to possess the right to make or to represent the law [...]. The archons are first of all the
documents' guardians. They do not only ensure the physical security of what is deposited
and of the substrate. They are also accorded the hermeneutic right and competence. They
have the power to interpret the archives. (Derrida 1995, 2)

It is the hermeneutical power of the curator/archivist/editor that makes the study of the archive crucial to our thinking about knowledge systems, heritage systems, and literary systems that rely on a synchronization of artistic value in order to execute inclusions in and exclusions from the sanctified corpus. For instance, if a writer has received the Nobel Prize in Literature, he/she, along with his/her literary production, can travel transnationally, no visa required.

Privilege acquired through the intersection of this literary law with a work's singularity confers literary clout on resistance writers from Eastern Europe. What makes a work internationally valuable? How do political and economic relations add to its literary value and prestige? Following Derrida, I argue that the canon, and even international prizes-as-heritage-archives, are always already politically and culturally motivated, and that assigning literary merit to a work through the prize-as-archive and critical-acclaim-as-archive also inserts the singular work into a "single corpus [...] [where] all the elements articulate the unity of an ideal configuration" (Derrida 1995, 3). After all, in the gathering together of knowledge, the archive also makes possible the total destruction of this knowledge through assimilation into a synchronic whole.

Therefore, in establishing a corpus of world artistic achievement, a world heritage of letters, an archive, and a library of humanity's best and brightest, international literary prizes and world literature critics also erect institutions that reside 
in the force fields of international relations and interests. Fluency in these force fields can ensure an entry into the "archive.” Knowledge of Cold War paranoia within and without the Eastern European fortress could afford enough ideological fluency to fuel Cold War narratives.

Examining these force fields in the case of Vladimir Nabokov's writing, Nataša Kovačević contends that his work is ideologically fluent in the Eastern and Western markets, whereby fashioning Kinbote in Pale Fire as a "martyred exile" aligns him with Western conceptions of Eastern Europe but Kinbote ultimately remains exotic and other, despite the Western invitations to emancipate his otherness $(2008,6)$. It is this inclusion through exclusion that continues to maintain the division, and even ideological hierarchy, between Eastern and Western literary traditions vis-à-vis their divergent political traditions. Nabokov is an interesting case study because of his existence between Eastern and Western letters and his ideological fluency in both. A closer critical analysis of Eastern European writers widely translated and studied in Western markets and the Western academy, reveals a similar pattern to Nabokov. These writers are often recipients of major international prizes awarded from Western literary centres, of which the Nobel Prize in Literature is prominent.

The Nobel Prize in Literature is guided by principles of literary achievement beyond a work's local context. Since its inception in 1901, the Nobel Prize in Literature has been awarded to writers from various regions of the world. Through the years, twenty-two of these prizes have been awarded to writers from Eastern Europe, and most of them were awarded between 1958 and 2009. The most recent writer with ties to Eastern Europe to receive the prize was Svetlana Alexievich in 2015; she was born in Ukraine but resided in Belarus at the time she received the prize. Eastern European authors enjoyed an increase in Nobel Prize awards between 1958 and 1987, when it appears that an Eastern European author received the prize every two to five years. This spike is not representative of the overall awarding patterns of the Swedish Academy, but it does serve as an example that highlights problems with literary prizes such as the Nobel in relation to theories of world literature, literary canons, and the knowledge production they provide, which are tied to foreign policy and diplomatic relations.

The discussion in the following pages is rooted in two theoretical paradigms that help us think about literary prizes and their role in shaping world literary heritage. First, we will look at literary awards as sites of knowledge production, and, in the Foucauldian tradition, this knowledge will be coded as power. Second, literary awards curate knowledge production and access to the knowledge produced, much like what Derrida argues regarding the role of archives in knowledge production and consecration. The implications here are twofold. There is the theoretical problem of how literary prestige shapes world literature because 
of its ties to the national and the global. In addition, literary prizes pose a methodological problem in the field of literary studies: how do we teach world literary traditions in Western universities? Do literary prizes consecrate reading choices? Are they arbiters of what claims a voice in what Pascale Casanova calls the "world republic of letters"? If so, what are the formal elements that qualify texts to have such prestige; and, more importantly, are these formal elements representative of the world? Derrida's analysis of the archive compels us to be deeply sceptical of international prizes as sites of inaccessible archives - inaccessible insofar as they obscure the political and historical interests that largely determine the winners, and therefore obscure the political motivations of the prize as a whole. Additionally, Derrida's archive compels us to link the literary and the political on the level of literary circulation and to interrogate the structures of literary power.

In his most cited and often controversial study, Orientalism (1978), Edward Said's goal was not merely a critique of Western representations of "the other"; rather, as he clarified in a later book, Culture and Imperialism, the link between cultural knowledge, capital, and political power is a direct one with observable consequences. In identifying the "forms of knowledge affiliated with domination" (Said 1993, 9), Said argued for a literary criticism that combined formal analysis of literary texts with their geopolitical position, and consequentially with ideologies that facilitated the cultural product's circulation or mobility/immobility.

What is relevant for our purposes here is Said's methodology, which combined literary analysis with social and cultural criticism. In linking political implications to literary circulation, production, and interpretation, Said opened up the possibility for a contextual literary criticism. Increasingly, in recent decades, "the Literature Prize has [...] carried something of [...] [a] moral burden [...] as it has come [...] to favor writers of strong political conviction who have become icons of moral leadership in their particular national or subnational communities” (English 2005, 630). Examples include Wole Soyinka, Nadine Gordimer, Toni Morrison, and Gunter Grass, "all of whom have received multiple humanitarian awards to arrange alongside their literary trophies" (English 2005, 630). Perhaps leaning towards a work's political import is inevitable given the representational relationship between fiction and history. In areas of political and economic unrest, the writer often embodies the political consciousness of the masses; the writer is almost an ethical and moral compass that exists beyond political and economic interests. And since literature aims to narrate those most human moments, it cannot do so by separating an individual's existence from the political forces that shape our lives. Therefore, it is no surprise that politically engaged writers are also the best received locally, and the ones awarded global literary recognition.

Although the Nobel Prize in Literature is the most international literary prize, it is also the most national one, because a recipient of the prize becomes 
a cultural icon and monument. The internationally consecrated author emerges as even more immortal in the national memory of his/her country of origin. The Nobel Prize in Literature also allows the construction of a national heritage along the international. Often, national literary capital is denationalized for international use, which, in turn, benefits the national. It is a national piece of literary real estate that is recognized as such, because "literary heritage is a matter of foremost national interest," especially given its essential link with language as a crucial marker of nationality (Casanova 2004, 34). Therefore, writers like Svetlana Alexievich, Herta Müller, Imre Kertész, Czesław Miłosz, Milan Kundera, Vladimir Nabokov, and Ismail Kadare have come to be thought of as national treasures and as belonging to a world literature canon, ${ }^{1}$ if only by virtue of their extensive translation into multiple languages and their works' wide circulation.

As indicated earlier, the Eastern European spike in reception of the Nobel Prize coincides with the years of the Cold War. Cold War literature from Eastern Europe that was praised by the Nobel Prize committee ought to be recognized for its "global reach" as a "lived experience" with a "psychological impact on populations" and a "determining influence on patterns of belief, identity, cultural practice and social formation" (Hammond 2012, 2). Fiction in the hands of Eastern European writers assumes the form of a political text whose value rests on its ability to influence "diplomatic and military history" while it depicts "life experiences of populations living under the Soviet and Western political and socio-economic systems," thereby achieving "fictional interventions in the historians"” long debate (Hammond 2012, 3). Hammond argues: “That novelists were not only social commentators but also foot-soldiers in a global Kulturkampf is evidenced by the superpowers' choice of authors for translation, for inclusion on educational syllabi and for the receipt of Nobel Prizes" (2012, 3). Along these lines, it is crucial to read fiction in Eastern Europe as part of a world literature that reflects the way texts circulate - a circulation that, crucially, reflects the dialogic and representational character of a literary exchange that irrevocably changes the cultures engaged in it.

Given the literary market's dialogic character - what is produced and circulated is determined by the relationship between the author's culture and the host culture - there is a need for a closer evaluation of the increase in awards given to Eastern European writers by the Nobel Committee during the Cold War. The award of the Nobel Prize to Eastern European writers is a unique case study that highlights the lingering effects of the East-West divide, and how this binary is

1 Kundera, Nabokov, and Kadare were never awarded the prize, but were frequently cited as contenders. 
also reflected in literary production, reception, and circulation. That this spike in awards correlates with the Cold War is only part of the puzzle. The question remains: why and what does this correlation indicate? Here we must pause to contextualize, briefly, the nature of the relationship between the two Europes.

Common representations of Eastern Europe are problematic, as Larry Wolff's Inventing Eastern Europe: The Map of Civilization on the Mind of the Enlightenment demonstrates. Wolff writes that, beginning with the Enlightenment, Western and Eastern Europe were invented simultaneously "as complementary concepts, defining each other by opposition and adjacency" $(1994,5)$. Consequentially, the binary between Western and Eastern Europes extends to their political, economic, and cultural relations. Kovačević extends Wolff's argument, writing that Western European representations of Eastern Europe are characterized by descriptions that try to classify and fix it "into stereotypes of lamentable cultural, political, and economic backwardness” (2008, 2). Dissident and exile narratives from Eastern Europe that have garnered critical acclaim in Western literary markets rely upon and further augment these attitudes.

Often, these narratives disavow Communist dictatorships of the Cold War, depicting the bleakness and oppression of civilians under ruthless regimes. At other times, writers from Eastern Europe depict an Eastern Europe that is "civilized, developed, tolerant, or multicultural enough to be geo-graphed as European” (Kovačević 2008, 3). Scholars like Kovačević and Wolff draw attention to the geopolitical relationships that have an effect on the way in which texts are received. In order for an Eastern European writer to gain a voice in the world republic of letters during the Cold War, he/she needs to offer literary innovation as well as content that speaks to the imaginary of the literary market abroad. In order for a writer to be a contender for the Nobel Prize in literature, critical acclaim ought to be significant enough to set the writer apart and make his/her work exceptional, an exceptionality that is circumscribed by an already approved universality.

The Kadare case is especially interesting. While he enjoyed widespread critical acclaim for his novels internationally, his status as dissident was simultaneously cemented in the aftermath of the fall of the Communist regime in 1991 and challenged by critics who believed that Kadare did not suffer loss or threat during the totalitarian Albanian regime. Following the logic of the latter critics, Kadare is not a real dissident, and therefore his work does not sufficiently condemn and disavow the totalitarian state. Kadare's position within the world of literary criticism is as precarious as his position within the Communist regime. He does not cleanly belong to the category of the "bad" party hack writer, nor does he belong to the "good" anti-Communist dissident camp. Kadare occupied both roles as he navigated life as a writer in a staunchly Communist nation. As a result, his place 
in the world republic of letters is also precarious insofar as his tactical manoeuvring - literary and political - during Communism blurs the line between conformist and dissident, which in turn, questions the validity of either category as a measuring stick for good and legitimate literary production. Kadare's figure in world literature, therefore, creates a crisis of categories: what place do writers like Kadare, whose works do not obey strict classifications, have in the orderly world archive of literary achievement?

Traditionally, his works are analysed as allegories of oppression. Kadare's numerous interviews with the foreign press insist on the universality of his vision, extending the effect of dictatorship beyond Albania's experience and into a more broadly human one. In an interview with Eric Faye in 1991 he stated: “The critics forget that in a dictatorship, the most massive war is not against the dissidents, but in an almost universal and mythological fashion, it is against human life. In order to rule a country, a dictatorship's aim is to transform human identity by creating an alternative universe, one where dictatorship can thrive" (Faye 2007, 115). ${ }^{2}$ Kadare contours his work as significant beyond his country's dictatorial context. As early as 1991, Kadare sought to position himself as a writer whose work has universal value, and therefore world literary value, a gesture that displays his ideological fluency in literary markets and international circulation.

Aside from being one of the intellectuals who spoke out against censorship, Kadare is an Albanian writer whose works were published outside of Albania to much critical acclaim, and as such, his works served as a keyhole through which the world tried to get a glimpse of Communist Albania. According to Peter Morgan, Kadare is "the last great chronicler of everyday life under Stalinism" $(2006,7)$. During a time when Enver Hoxha's regime persecuted and even executed artists who were subversive to the government and state, Kadare had a surprisingly good relationship with the government. This curious relationship is closely examined in Peter Morgan's The Writer and the Dictatorship (2013). Morgan argues that Hoxha was a learned man who valued Kadare's contribution to Albanian letters. He displayed leniency towards Kadare when some of his writings were deemed transgressive by the Party's analysts: Kadare's punishment consisted of short-term exile to a small town in central Albania. Morgan argues that Hoxha's tolerance towards Kadare was a direct result of the former's respect for litera-

2 "Kritikët harrojnë gjithashtu diçka tjetër, se në një diktaturë lufta me titanike nuk është ajo kundër disidentëve, por, në një mënyrë më mitike dhe më tërësore, është lufta kundër jetës njerëzore. Për të sunduar në një vend, një diktature i duhet të shpërfytyrojë jetën njerëzore, ta zëvendësojë duke krijuar një univers ndryshe, pa të cilin ajo nuk do të imponohej dot.” All translations from Albanian are mine. 
ture and the arts, and the fact that Kadare was the only Albanian writer whose work received international acclaim. Such an assessment has validity, but local critics experience unease with Kadare's relationship with Hoxha, and many reject Kadare's status as a dissident writer, which they view as a label that is inaccurate and one that is primarily in service of international literary markets.

These notes on the Kadare case are helpful in contextualizing his oeuvre; but more importantly, they serve as a counterbalance to the international critical praise of Kadare's work. The Western press applauds his ability to speak about the human condition through his allegories. Kadare has been cited as a contender for the Nobel prize numerous times, and while there is no doubt that his literary achievements are many and worthy of a writer of world literature, little has been done to understand the role that translation has in the Kadare oeuvre. His works have been translated worldwide, and he was the first Man Booker International Prize recipient, but the kind of translation I have in mind has to do with Kadare's ideological fluency and the works of the critics that translate the ideological import of his texts.

I will use two brief examples from Kadare's writing to highlight how paranoia in the texts themselves mirrors the paranoia of the Cold War, which relies on Western audiences' preconceived attitudes about Eastern Europe and aids a Western audience's recognition and acceptance of the text. Kadare's novel Gjenerali i Ushtrisë së Vdekur [The General of the Dead Army] (1963) is one of his most critically acclaimed texts. The narrative takes place in post-World War II Albania, where an Italian general travels through the countryside in order to exhume the remains of dead Italian soldiers and return them home. The general is haunted by suspicion and fear. His paranoia stems from his precarious position as an Italian general in a foreign land whose exhumation of bodies serves as an opening of old wounds. From the opening passages of the novel, Albania's landscape is threatening and dangerous. Kadare writes: "He could see from the plane's window up above the threatening mountains, whose sharp peaks could at any time pierce the plane's belly. The mountainsides plummeted sharply into the fog below, and it was in these plunging cliffs and within all the wintering valleys around, heavy under the cold rain, that he could almost see the slumbering army he would untomb" (Kadare 1981, 10). ${ }^{3}$ The land itself is hostile, its mountains have nefarious intent, and the general's paranoia is justified. Certainly, these descriptions

3 "Për një kohë të gjatë, nga xhami i aeroplanit, ai kishte vështruar pamjen kërcënuese të maleve. Majaet e tyre të mprehta dukej sikur do të gërricnin në çdo cast barkun e avionit. Tokë e pjerrët kudo. Pllaja të zymta që rrëshqisnin me shpejtësi poshtë mjegullës. Në ato hone e pjerrësira dhe nëpër gjithë rrafshnaltën dimërore, dergjej nën shi ushtria që ai po vinte ta zhvarroste.” 
add to the macabre and surreal duty the general must fulfil, but they also rely on tropes that position Eastern Europe as the other: unknown, threatening, and inhospitable. Ultimately, the general returns home, but not before he experiences a mental breakdown upon witnessing the ravages of war in the lingering wounds of the Albanian people he meets during his travels. Even as he embarks on the plane to go back to Italy, Albania is engulfed in sleet and snow, a cold and calamitous land that remains a mystery.

A similar scenario can be observed in Kështjella [The Siege] (1970), a novel about an Ottoman siege of an Albanian stronghold in the fifteenth century. The novel depicts the long siege and the methods the Ottoman army used to break the Albanian stronghold. Much like in The General, the narrative is focalized on the military figure, the pasha, who is the leader of the Ottoman army. Here, too, the Albanian landscape itself hints at the perilous campaign: "Never had he seen such mountains. They resembled a heavy anxiety that continually pressed on one's chest with no alleviation. It was as if the earth and rocks were hurled with a fury towards the sky, breaking all natural law. Allah must have been angry when he created this land, he thought" (Kadare 1981, 9). ${ }^{4}$ Hostility, danger, madness, and ultimately failure are the experience for both the general and the pasha. Albania remains alien, pernicious, and full of terror that haunts these protagonists, driving them to paranoia and madness. Their paranoia mirrors the paranoiac views of Eastern Europe behind the Iron Curtain, and, as such, it presents an intelligible narrative of easterness that the Western reader can recognize.

As these concise examples show, Kadare's prose relies on already established tropes of Eastern Europe as other, mysterious, and dangerous. The Eastern European subject and its lands were quarantined during the Cold War because the Iron Curtain "separate[ed] the light of Christian civilization from whatever lurked in the shadows" (Wolff 1994, 2). As a world literature writer, Kadare recognizes and internalizes these tropes in his prose. Beside the artistic value of Kadare's oeuvre, it is also this ideological fluency of Kadare's texts that help them travel widely throughout the world. They are Eastern European narratives speaking to Western audiences. To vary a phrase of Rebecca Walkowitz (2017, 20), Eastern European writers' works written during the Cold War are born ideologically fluent. At the centre of such fluency is the idea of dissidence and its role in aligning the Eastern European text with Western conceptions of easternness. Kadare's works perpet-

4 "Asnjëherë nuk kishte pare male të tilla. Ato i ngjanin një ankthi të rëndë që të shtyp e të shtyp vazhdimisht dhe nuk të lë të zgjohesh. Toka dhe gurët ishin vërvitur me një furi të tillë drejt qiellit, saqë dukej se I kishin thyer të gjitha ligjet e natyrës. Allahu do të ketë qenë i nevrikosur kur krijoi këtë vend, kishte menduar ai." 
uate somewhat the orientalization of the Eastern European other, but they also display the demands of literary markets. And if dissidence and disavowal is one secret passageway into the world literary market, then it is also an avenue through which stories from otherwise forgotten corners of the world can be heard.

We would be remiss to discuss the demands of a Western-dominated literary market if we did not also acknowledge the role that diaspora had in establishing dissidence as the revolutionary expression par excellence. In "Resistance and Dissent in Central and Eastern Europe," Barbara Falk writes: "Much of the early attention to resistance and dissent did not come from the academic community, but from émigré communities, particularly concentrated in West European capitals and in the larger multicultural cities of North America such as New York, Chicago, and Toronto" (Falk 2001, 325). Émigré communities shaped the Western understanding of the conditions of citizens in Eastern and Central European nations; they published pamphlets and magazines that argued for a swift overthrow of the Communist spectre in the region, and they were instrumental in shaping public opinion in the West and garnering diverse academic interest in the area.

Academics in the West, following the lead of émigrés from Eastern Europe, began to study the texts of Eastern European writers in addition to theorizing the nature of resistance, dissidence, and exile. Initially, the consensus on resistance and dissidence focused on the ability of these social expressions to mobilize populations to emerge out of oppressive regimes, but as the Cold War continued, academics in the West started to view "open dissent [...] as a subset of the larger category of resistance to communist rule” (Falk 2001, 320). Theories on dissent emphasize its fluid and organic nature, which makes its varied expressions challenging to classify and categorize. Speaking on the nature of resistance, James C. Scott argues that resistance and dissent are often manifested as "hidden transcripts": gossip, folk tales, songs, stories, jokes, and so on. So long as a hidden transcript is impregnated with a critique of power, it is successful in expressing dissent in the name of those who are powerless (Scott 1990, xiii). Scott's theory of hidden transcripts complicates our understanding of dissidence, and it acknowledges that "there is no clear-cut line between resistance and dissent - it is more of a continuum or full spectrum" (Falk 2001, 321). A writer's place in this spectrum also determines his/her place in the world republic of letters, because literary studies on Eastern European literature rely on the binary of dissident vs conformist. Falk writes:

Prior to 1989, the grand narrative of dissent and resistance to authoritarian Communism across the region was primarily a Western enterprise, constructed by a rich community of scholars, activists, émigrés, and journalists. Although networks of East-West transnational interaction were quite dense considering the obstacles of highly controlled borders, prac- 
tices of censorship, and authoritarian surveillance, the imperatives of getting texts and information out to and back from the West, getting Western governments to pay attention to what was happening in the East, and garnering émigré support were powerfully determinative. (Falk 2001, 338)

Falk's historiography of dissident and resistance writing shows that the aim of émigrés was to draw attention to difficult realities in their home nations in order for Western nations to engage in diplomatic and political action. Such action could only be taken if there were enough accounts - artistic and literary - that served as keyholes through which the other Europe could be glimpsed. Insofar as the role of resistance and dissident writers in Eastern Europe was defined by this function, their literary production, too, served information output, which itself served a larger political project: releasing Eastern Europe from the Soviet spectre and from its inherent otherness.

Therefore, assigning texts value for their political and diplomatic service is an important factor that determines whether a work travelled into the more opulent Western markets. To that end, writers from Eastern Europe during the Cold War and shortly thereafter assimilated this function of their text, and their literary works were born ideologically fluent, certain of the role they played in a larger historical and political arena. Kadare is one such writer. Peter Morgan writes: "For the Western left, Kadare's greatest fault was his failure to speak out against the regime. They wanted a Solzhenitsyn, or a Havel, a heroic dissident in the post-totalitarian mould." It was impossible to survive as a dissident "in the only European Maoist state," which explains Kadare's compromise with the regime and his hidden dissent through highly allegorical works. Kadare's resistance was enacted through hidden transcripts, or through what Ralf Dahrendorf calls "inner emigration" (Morgan 2010, 307), which is not as heroic as a suffering dissident's protest, but which preserves a writer's life in order to allow for literary production to flourish. The texts themselves become the foci of resistance and a testimony to the fortitude of one's artistic vision in the face of adversity. Kadare's place in world literature reminds us that the position of writers from small nations and minor linguistic traditions is dependent upon the literary market's demands. Stories ought to have universal applicability, of course, but they must also recontextualize and represent visions of a world that is different but familiar. It is this difference in familiarity that constructs what we have called ideological fluency: the collection of internal and external historical and political demands that determine a work's place within the world republic of letters, and a work's belonging to the archive of world literature.

I will return to my initial remark on the Nobel Prize in Literature to emphasize how, as an institution of literary consecration, it too subscribes to ideological 
fluency. Upon surveying the Nobel committee's rationale for awarding the prize, we note phrases like "human destinies drawn from the history of his country," "universal human conditions," "modern man's struggle for freedom and creativeness," "man's exposed condition in a world of severe conflicts," "the indomitable spirit and versatility of man," "fragments of human reality," "forgotten face of history," "fragile experience of the individual," and "clash and interlacing of cultures" ("All Nobel Prizes in Literature” 2018). These phrases are as vague as they are politically motivated. There is a sense of urgency when the prize appeals to the unbroken human spirit, to the individual struggle in the face of unjust history, to the clash of civilizations, and to the fragmentation experienced in fictional and poetic accounts coming from Eastern Europe. This urgency is possible precisely because of already determined attitudes about the darkness and oppression on the other side of the Curtain, and narratives from Eastern Europe that even indirectly confirm these suspicions are met with critical acclaim. It is the paranoia of the Cold War that drives the spike in Eastern European laureates. This is not to say that there is no artistic achievement to be found. On the contrary, the Nobel laureates are well-deserving of the title, but we must also keep in mind the value of the Nobel Prize's consecration. Authors like Müller, Pamuk, and Kertész are part of a literary canon that values uniformity - singularity that adheres to the accepted universal - a canon that obscures difference, that is normative, and that ultimately seeks to assimilate individual, local, specific, and national through a vague appeal to strength in the human spirit and literary innovation.

The most recent example of the aforementioned East-West attitudes behind the Nobel Prize can be detected when professor Horace Engdahl presented the prize to Orhan Pamuk in 2006. Speaking about Pamuk's novel Snow (2002), Engdahl declares that Ka, the novel's central character, travels into a "forgotten town on a remote Turkish border. This displacement, no less drastic than a journey from Earth to Moon, gives him the opportunity to take a geological core sample of all levels of Turkish society" (2018). For Engdahl, Turkey's difference from Europe is as significant as the difference between earth and moon. Engdahl's position as a European professor and a prominent member of the Swedish Academy awarding the most prestigious literary prize to a Turkish author, reveals how these subject positions determine literary interpretation and world literature status. If we follow Engdahl's analogy, we may be compelled to ask: which is the planet and which is the satellite? Which is the centre and which is the periphery? Even more curious, however, are Engdahl's words about Istanbul's consecration as a literary centre: "You have made your native city an indispensable literary territory, equal to Dostoyevsky's St. Petersburg, Joyce's Dublin or Proust's Paris - a place where readers from all corners of the world can live another life, just as credible as their own, filled by an alien feeling that they immediately recognize as their own" (Engdahl 
2018). It is as though Istanbul did not exist as a literary and artistic centre prior to Pamuk's acceptance of the Nobel Prize in Literature. Engdahl's words are self-affirming and literary centre-building. As if by waving a magic wand, Istanbul emerges as an important literary centre and appears on the map of literary circulation. Such a gesture is a kind of consecration that assumes supreme authority over the literary market, and which adheres to Derrida's description of the archive as a closed and opaque repository of knowledge. Pamuk can be part of the museum of world literature only if he fits the archive's logic of belonging. It is certainly significant that Pamuk is recognized for his literary achievement and contribution to world literature, especially in a post-9/11 setting, and during a time when we are witnessing the rise of fundamentalisms worldwide. But the question remains: what is significant about being consecrated into the world literary canon, if the body of knowledge and the logic of its construction is behind closed doors and inaccessible to those who wield little political and literary power?

\section{Works cited}

“All Nobel Prizes in Literature." nobelprize.org. Nobel Media AB, 2018. https://www.nobelprize. org/prizes/uncategorized/all-nobel-prizes-in-literature/ (18 September 2018).

Casanova, Pascale. The World Republic of Letters. Cambridge: Harvard University Press, 2004. Damrosch, David. What is World Literature? Princeton: Princeton University Press, 2003.

Derrida, Jacques. Archive Fever: A Freudian Impression. Trans. Eric Prenowitz. Chicago: University of Chicago Press, 1995.

Engdahl, Horace. "The Nobel Prize in Literature 2006 - Award Ceremony Speech." 2006. nobelprize.org. Nobel Media AB, 2018. https://www.nobelprize.org/prizes/ literature/2006/ceremony-speech/ (7 August 2018).

English, James F. The Economy of Prestige: Prizes, Awards, and the Circulation of Cultural Value. Cambridge: Harvard University Press, 2005.

Falk, Barbara J. "Resistance and Dissent in Central and Eastern Europe: An Emerging Historiography." East European Politics and Societies 25.2 (2001): 318-360.

Faye, Éric. Tri Biseda me Kadarenë. Tirana: Onufri, 2007.

Hammond, Andrew. Global Cold War Literature: Western, Eastern and Postcolonial Perspectives. New York: Routledge, 2012.

Kadare, Ismail. Gjenerali i Ushtrisë së Vdekur. Tirana: Naim Frashëri, 1981.

Kadare, Ismail. Kështjella. Tirana: Naim Frashëri, 1981.

Kovačević, Nataša. Narrating Post/Communism: Colonial Discourse and Europe's Borderline Civilization. New York: Routledge, 2008.

Morgan, Peter. “Ismail Kadare: Modern Homer or Albanian Dissident?" World Literature Today 80.5 (2006): 7-11.

Morgan, Peter. Ismail Kadare: The Writer and the Dictatorship 1957-1990. New York: Routledge, 2010.

Said, Edward W. Culture and Imperialism. New York: Vintage, 1993. 
Scott, James C. Domination and the Arts of Resistance: Hidden Transcripts. New Haven: Yale University Press, 1990.

Walkowitz, Rebecca. Born Translated: The Contemporary Novel in an Age of World Literature. New York and Chichester: Columbia University Press, 2017.

Wolff, Larry. Inventing Eastern Europe: The Map of Civilization on the Mind of the Enlightenment. Stanford: Stanford University Press, 1994.

Eralda L. Lameborshi is a lecturer in the Department of English and Creative Writing at Stephen F. Austin State University. Her area of expertise is twentieth-century Eastern European literature, historical novels about the Ottoman Empire, migration literature, immigration and exile, Eastern European cinema, postcolonial theory, and film theory. She is currently working on a book manuscript entitled The Islamic Empire and World Literature. 
